\title{
Interstate and International Distinctions in Conflict of Laws in the United States
}

\author{
Eugene F. Scoles*
}

$\mathrm{O}$ VER A PERIOD OF MANY YEARS Professor Ehrenzweig has persistently urged the separate treatment of interstate and international conflict of laws problems. ${ }^{1}$ Other writers have also pointed to the significant differences of policy in particular interstate and international conflict cases. $^{2}$ It is the purpose of this article to explore these suggestions in light of current developments in this field of the law.

\section{I}

\section{DOGMA AND DOCTRINE OR POLICY AND METHOD}

Many of the suggestions for a separate treatment of interstate and international conflicts problems reflect an assumption that courts will either apply fixed doctrinal rules or will not adequately consider the variations in policy applicable in international cases. Unfortunately, there have been sufficient instances in the past in which the courts and the parties have appeared to do this to warrant serious concern. ${ }^{3}$ If a court is wedded to dogma, justice may not be served unless the court distinguishes between interstate and international cases. To apply mechanically a rule developed in interstate cases to an international situation without a consideration of its policy relevance is both wrong and danger-

* A.B., 1943, J.D., 1945, University of Iowa; LL.M., 1949, Harvard University; J.S.D., 1955, Colunbia University; Professor of Law, University of Illinois.

1 Ehrenzweig, Conflict of Laws $\$ 6(1962)$; Emrenzweig, Fragistas \& Yiannopoulos, American-Greek Private International Law 56 (Bilateral Studies in Private Int'l Law No. 6, 1957); Ehrenzweig, Imerara \& Jensen, American-Japanese Private InternationaI Law 41 (Bilateral Studies in Private Int'l Law No. 12, 1964); Ehrenzweig, Interstate and International Conficts Law: A Plea for Segregation, 41 MINN. L. REv. 717 (1957).

2 Cavers, $A$ Critique of the Choice of Law Problem, 47 Harv. L. Rev. 173, 197-203 (1933); Cheatham, American Theories of Confict of Laws: Their Role and Utility, 58 Harv. L. Rev. 361, 394 (1944); Dubois, The Significance in Conflict of Laws of the Distinction between Interstate and International Transactions, 17 MINN. L. REv. 361 (1933); Goodrich, Directive or Dialectic, 6 VAND. L. REv. 442, 445 (1953); Leflar, Choice Infiuencing Considerations in Conflicts Law, 41 N.Y.U.L. REv. 267, 285 (1966); Yiannopoulos, Wills of Movables in American International Conflicts Law: A Critique of the Domiciliary Rule, 46 Cartr. L. Rev. 185, 187 (1958); Cavers, Book Review, 47 CaIIF. L. Rev. 414, 415 (1959).

3 See Walton v. Arabian Am. Oil Co., 233 F.2d 541 (2d Cir. 1956), cert. denied, 352 U. S. 872 (1956). Conversely, international concepts have also distorted interstate law. For example, the jealous sovereign doctrine of refusing to enforce foreign tax claims has no place in a federal systen and hittle in the international. $C f$. City of Detroit v. Proctor, 44 Del. 193, 61 A.2d 412 (1948); EHRENZWEIG, CONFITCT OF LAWS $\$ 49$ (1962); GoOdricH, CONELICT of LAws $\S 66$ (Scoles ed. 1964) [hereinafter cited as GoodricH]. 
ous. Consider the case of two Americans traveling abroad together in several foreign countries who agree to a loan in dollars from one to the other to be repaid im dollars at home. Absent other facts, there seems no reason to assume that justice is served by applying the law of the country where the parties happened to be at the time of their agreement. ${ }^{4} \mathrm{~A}$ fortiori, it would not seem appropriate to require the lender to prove the law of that country and his rights thereunder in an action brought in the Umited States ${ }^{5}$ against his former friend. It is highly untikely that a court would apply the foreign law in such a case; it would instead use one of the many available means to sustain the agreement by application of a law more closely related to the parties and their expectations. ${ }^{0}$ If the court, following a doctrinal scheme of conflicts, should treat this international case as outside the doctrinal structure applicable to interstate transactions, it then might well be forced to consider the policies underlying the available alternatives and thus to develop a solution more in keeping with current needs. Once this procedure has been attempted in the international area, reconsideration of some of the interstate "leirlooms" might be attempted, thus improving the disposition of both international and interstate cases by treating them under separate structures of doctrine. ${ }^{7}$

On the other liand, if a court is less doctrinally minded and in all cases thoroughly considers both the policies underlying the problem and the available legal solutions, the differences between interstate and international transactions will probably be accommodated in its final result. ${ }^{8}$ For example, if the alleged defect in the contract in our case of the "short" tourist were a foreign government's prolibition on unapproved contracts for foreign exchange which was designed to prevent local citizens from removing local capital from the country, the "thinking" court would identify the false conflict and limit the prohibition to cases having a relation to its purpose. The court's conclusion that the foreign exchange rule was irrelevant to the issue at liand would avoid the need to construct an "international rule" for such a case.

In brief, if conflict of laws is viewed solely as a body of doctrinal rules to be applied according to fixed contacts, separate bodies of rules for interstate and international transactions must be developed. If, however, conflict of laws is essentially a method or an approach for the solution of

${ }^{4}$ Cf. Leary v. Gledhill, 8 N.J. 260, 84 A.2d 725 (1951).

5 Cf. Walton v. Arabian Am. Oil Co. 233 F.2d 541 (2d Cir. 1956).

6 EHrenzweig, Conflict of Lilws § 175 (1962).

${ }^{7}$ Cf. DuBois, supra note 2, at 379.

8 See Cavers, The Choice of Law Process 117 (1965); Katzenbach, Conflicts on an Unruly Horse: Reciprocal Claims and Tolerances in Interstate and International Law, 65 YaLE L.J. 1087, 1118-19 (1956). 
interstate or international problems of private litigants, then the necessary distinction will be built into the policies that guide the court to a solution.

In the past forty years the United States has seen a substantial transition in conflict of laws from dogma to an evolving method of analysis and prediction based on a consideration of the relevant purposes and policies. This method has been described by Cavers as follows:

The new conception views the basic problem as how to make that choice between conflicting laws which will best accommodate conflicting state policies. This renders it necessary first to identify the respective policies and to decide whether they truly conflict, whether the application of one law will defeat or impair the pohicy objectives of the other. ...

Where analyses of the policies underlying apparently conflicting laws do not reveal the conflict to be false, nevertheless study of the circumstances of the transaction or event out of which the controversy lias arisen may disclose that the reasons for the application of one state's law are significantly stronger than the reasons for applying the law of the other state. ...

In making such an assessment in the case supposed and in other cases involving the same issue, the court could inquire into, and take account of, the reasonable expectations of the parties in determining low far to press the claims of the respective state policies. This might be a neutral factor in some cases; in others, it could well be decisive.

This approach to the choice of law differs sliarply from that embodied in the original Restatement in two respects that are of importance. ...

First, the new approach recognizes that the problem confronting the court is a choice between two particular rules of law to govern the issue before the court; it is not a problem of choosing between two legal systems im their entirety and accepting in advance whatever might, on inspection, prove to be the relevant rules in these two systems. Only if the court is choosing between particular rules can it identify the respective policies embodied in those rules and decide whether they present a true conflict, and, if so, which law appears to have the better claim to application in the liglit of the facts of the case, including the expectations of the parties. This means that a few simple rules of wide sweep are not likely to be developed; instead, it offers the hope that decisions based on discriminating assessments of policies and expectations will gradually build up a body of differentiated rules to which courts can adhere and which they can steadily develop. . . .

Second, if the basic task of the courts in a choice-of-law case is not to apply broad jurisdiction-selecting rules that ignore the content of the state laws closen but rather to identify state policies and to determine the significance for those policies of their application or

- Cf. Cavers, Re-Restating the Confict of Laws: The Chapter on Contracts, in TwENtieth Century Comparative aNd Confricts Law 349 (Nadel ed. 1961). 
non-application in interstate situations, then the most appropriate forum for the performance of this task is a court of a state whose policies are in issue. . . .10

If the foregoing is an accurate appraisal of the current development of conflict of laws technique in the United States, ${ }^{11}$ the problem becomes one of identifying and articulating the variations in policy considerations that lead to the solution of the particular problems posed to the court or counsel. In most situations the differences in policy and law between the forum and the other concerned jurisdictions are likely to be greater in international than in interstate cases. ${ }^{12}$ Because of this, and because American conflicts jurisprudence is in a state of continuing transition between fixed doctrinal rules and the flexible policy-oriented method, an attempt will be made to identify some of the areas in whicl policy considerations may differ to illustrate the need for continual attention to the different policies that are relevant in international and interstate conflict of laws.

II

\section{THE PUBLIC SPHERE IN CONFIICTS}

The differences between international and interstate cases vary with the particular factual situation involved. Some areas contain sharp distinctions in doctrine and policy, but in other areas the distinctions are neither great nor easily identified by attorneys trying the cases. The areas of sharp distinction tend to be those which are affected by public law considerations. These are areas in which there is a governmental interest separate from that which exists through the litigants.

\section{A. Foreign Relations and Treaties}

The sector perhaps most influenced by separate governmental considerations is that involving relations between the United States and foreign governments. Foreign relations are, by our constitution, exclusively within the control of the federal government. The national interest clearly predominates over any regional or state interest should there be a conflict. In United States v. Belmont, ${ }^{13}$ in which the New York court

10 Cavers, Change in Choice-of-Law Thinking and Its Bearing on the Klaxon Problem, in A. L. I., Study of Jurtsdiction Between State and Federat Courts, 154, 163-165, App. (Tent. Draft No. 1, 1963). See also Cavers, supra note 3, 63-75 (1965); Cavers, The Changing Choice of Law Process and the Federal Courts, 28 Law \& Contexr. Pros. 732, 733 (1963); Weintraub, A Method for Solving Conflict Problems-Torts, 48 ConNerc L. Q. 215 (1963). 11 "The last battle has not been fought, but the war has been won." Weintraub, supra note 10 , at 252 . See also GoOdrich 166-67.

12 See Cowen, American-Austratian Prtvate Internationat Law 9 (Bilateral Studies in Int'l Law No. 8, 1957); Weintraub, Book Review, 45 IowA L. REv. 979, 982 (1960).

13301 U.S. 324 (1937). 
declined to give effect to the Russian nationalization of the assets of a Russian corporation which had been recognized by the American government in the Litvinov Assignment, the Supreme Court stated:

Governmental power over internal affairs is distributed between the national government and the several states. Governmental power over external affairs is not distributed, but is vested exclusively in the national government. ...

Plainly, the external powers of the United States are to be exercised without regard to state laws or policies. . . . In respect of all international negotiations and compacts, and in respect of our foreign relations generally, state lines disappear. As to such purposes the State of New York does not exist. Within the field of its powers, whatever the United States rightfully undertakes, it necessarily has warrant to consummate. And when judicial authority is invoked in aid of such consummation, state constitutions, state laws, and state policies are irrelevant to the inquiry and decision. It is niconceivable that any of them can be interposed as an obstacle to the effective operation of a federal constitutional power. ${ }^{14}$

The dominance of the central government's power, when exercised in its proper sphere, over that of the states is effectively established by the supremacy clause of the United States Constitution. ${ }^{15} \mathrm{By}$ this provision treaties are accorded the status of supreme law. Accordingly, if there should be a treaty with provisions relevant to litigation between private individuals, it must be given effect against any contrary policy of the forum or any other state which has an interest in the litigation. ${ }^{16}$

In Kolovrat $v$. Oregon, ${ }^{17}$ an Oregon statute made inheritance by a non-resident alien dependent upon (1) the reciprocal right of a United States citizen to take property by inheritance in the alien's country, (2) the riglit of a United States citizen to receive money from estates in the ahen's country, and (3) proof that the alien would receive the estate funds without confiscation by his government. ${ }^{18}$ Under Oregon law

14301 U.S. at 330-31. See United States v. Pink, 315 U.S. 203, 233 (1942) "[T]he policies of the States become wholly irrelevant to judicial inquiry when the United States, acting within its constitutional sphere, seeks enforcenent of its foreign policy in the courts."

15 U.S. Const. art. VI.

${ }^{16}$ See generally, Bayitch, Confict Law in United States Treaties, 8 U. MIAMI L.Q. 501 (1954). The International Monetary Fund Agreenent is an example of a multi-state convention that has begun to hring some order to a chaotic area of international conflicts law. See Meyer, Recognition of Exchange Controls After the International Monetary Fund Agreement, 62 Yale L.J. 867 (1953); cf. Rashba, Foreign Exchange Restrictions and Public Policy in the Confict of Laws, 41 MICE. L. Rev. 777 (1943); Strong, Minimizing Monetary Risks in Foreign Trade, 1959 U. Inx. L.F. 355.

17366 U.S. 187 (1961).

18 OrE. Rev. Stat. § 111.070 (1965). These so-called "Iron Curtain" statutes raise many problems. See EnRENzweIG, Confuict of Laws 166, 668 (1962); Berman, Soviet Heirs in American Courts, 62 Colom. L. Rev. 257 (1962); Fulda, Legatees Behind the Iron Curtain, 
Yugoslavian citizens would have taken as heirs of an estate, but the Oregon court held they were precluded by the statute because Yugoslavia did not provide an unqualified right for aliens to receive property. The United States Supreme Court reversed and held that the 1881 treaty with Serbia, which now forms part of Yugoslavia, applied to give Yugoslavians the same rights to inherit "as they would [have] if they were American citizens living in Oregon." Notwithstanding the generally recognized view that succession is a matter left to the states by the Constitution, the presence of a treaty in an international case may impose a limitation upon the forum or a rule not subject to variation by the forum's statutes or usually applicable policy. For example, a treaty may give a testator a choice of applicable law which would not exist but for the international aspect of the case. ${ }^{20}$ Further, if the treaty includes a "most favored nation" clause, it may make the rule of still another treaty with a different country applicable. ${ }^{21}$

The strong force of the policies calling for a single national law which are reflected in the Belmont and Kolovrat cases suggest the possibility of a federal conflicts law covering all aspects of international transactions. ${ }^{22}$ When the recognized existence of a federal common law in areas of predominant federal interest ${ }^{23}$ is added to the picture, it seems somewhat surprising that there has not been greater development of such a separate "federal" conflict of laws rule. It remains a potential development as international transactions become more commonplace. So far, however, the United States Supreme Court has been willing to permit most conflicts problems arising in international transactions to be treated by state courts as normal state law questions; federal courts do the same thing by applying the Erie-Klaxon doctrine. ${ }^{24}$ Only when the Federal government has acted, by legislation, compact or treaty, within its sphere of concern, and the litigation in question rather directly involves such ac-

16 Omro S.B.J. 496 (1956) ; Heyman, The Non Resident Alien's Right to Succession Under the "Iron Curtain Rule," 52 Nw. U.L. REv. 221 (1957); Scoles \& Rheinstein, Conflict Avoidance in Succession Planning, 21 LAw \& Contearp. Prob. 499, 519 (1956).

10366 U.S. at 196.

20 Nussbaum, Amorucan-Swiss Private International Law 27 (Bilateral Studies in Int'l Law No. 1, 2d ed. 1958).

21 This situation existed in Kolovrat. The court relied on an 1853 treaty with Argentina which gave the same privileges of inheritance in the United States to Argentinians as native United States citizens. See 366 U.S. at 193-94.

22 Cf. EHRENZWETG, Confuict of LAWS \$§ 6-8 (1962); Cheatham, Federal Control of

Confizet of Laws, 6 VAND. L. REv. 581, 582 (1953); Leflar, Constilutional Limits on Free Choice of Law, 28 LAw \& Contemp. Prob. 706, 709 (1963).

23 D'Oench, Duhne \& Co. v. Federal Deposit Ins. Corp., 315 U.S. 447 (1942); Clearfield Trust Co. v. United States, 318 U.S. 363 (1943).

24 Erie R.R. v. Tompkins, 304 U.S. 64 (1938); Klaxon v. Stentor, 313 U.S. 487 (1941).

Cf. Ioannou v. New York, 371 U.S. 30 (1962). 
tion or relations with foreign governments have the courts found the national policies superior to those of the states.

\section{B. Judgments}

An interesting area of doubt and contradiction which is overdue for development involves the enforcement in the Umited States of judgments secured abroad. Here the infamous case of Hilton v. Guyot ${ }^{25}$ seems to establish the uncertain rule that a judgment secured in the courts of a foreign nation by one of its citizens in a suit brouglit by him against a citizen of the United States is subject to review on the merits, unless reciprocity is extended to similar judgments of United States courts in the foreign country. The Supreme Court in this much criticized case apparently had in mind only the policies relevant to coercive diplomatic negotiation, and perhaps not even all of those. ${ }^{26}$ In interstate cases, however, the full faith and credit clause of the Constitution ${ }^{27}$ has been held to require enforcement of foreign interstate judgments without exception for local policy reasons. ${ }^{28}$ The difference primarily reflects the need to weld the states together as a single nation with utmost freedom of interstate commerce and migration ${ }^{29}$ and with all states respecting each other's procedures. In the interstate area, variations in cultural attitudes and commercial practices are not great and eacli state's governmental procedures are subject to the same constitutional limitations. Althougl such variations may be greater in international cases, this should not justify a requirement that all foreign judgments be reviewed on their merits. Most countries provide litigants with fair and reasonable judicial procedures, and the fundamental policy of terminating litigation after final judgment has been rendered entitles their judgments to recognition elsewhere. ${ }^{30}$ Just as there is little reason for judicial concern over the differ-

25159 U.S. 113 (1895).

${ }^{20}$ Cf. Banco Nacional de Cuba v. Sabbatino, 376 U.S. 398 (1964); EHRENZWEIc, CoNFLICT OF LAWS $\S 48$ (1962).

27 U.S. ConsT. art. IV, $\$ 1$.

28 Roche v. McDonald, 275 U.S. 449 (1928); Union Nat'l Bank v. Lamb, 337 U.S. 38 (1949); Fauntleroy v. Lum 210 U.S. 230 (1908); GoopricH \& 211.

${ }^{29}$ See Ehrenzweig, Interstate and International Conficts Law: A Plea for Segregation, 41 MnNo. L. Rev. 717, 719 (1957).

${ }^{30}$ See Smit, International Res Judicata and Collateral Estoppel in the United States, 9 U.C.L.A.L. REv. 44 (1962), which explores the underlying policies suggesting recognition or nonrecognition and compares their force with respect to interstate and international judgments; Reese, The Status in This Country of Judgments Rendered Abroad, 50 Conom. L. Rev. 783, 784 (1950); Goodrich § 217; Restatement (SECOND), Conflict of Laws § 430(e) (Tent. Draft No. 11, 1965); cf. Scott v. Scott, 41 Cal. 2d 249, 331 P.2d 641 (1958). See generally UNIFORM FORETGN MONEX-JUdGMENTS ReCognITION ACx, 9B U.L.A. (Supp. 1965, at 28) (adopted in Illinois and Maryland). But cf. Rosenbaum v. Rosenbaum, 309 N.Y. 371, 130 N.E.2d 902 (1965) (4-to-3 decision). 
ences in dispute-settling procedures among the several states of the United States, there should be little cause for concern over differences among the nations that make up the common law world. The standards of justice common to these nations are such that the usual exceptions that we classify as jurisdictional limitations-that is, adequacy of notice, opportunity to be heard and the appropriateness of the forum entertaining the litigation-will sufficiently protect against the unusual case where a party takes unfair advantage of a local procedure. ${ }^{31}$ Differences in legal traditions and the unavailability of legal materials of the common law countries present fewer problems today than did interstate questions a few years ago.

Similar respect should be extended to the judgments of nations of the civil law system, for while language and methods concededly differ, just results are equally likely, given reasonable judicial procedures. Accurate translators and literature are becoming more and more available and we have some local experience with the civil law of Louisiana, Quebec and Mexico. The "jurisdictional" limitations of adequate notice, opportunity to be heard and appropriateness of the forum should likewise in this instance provide ample protection for parties in this shrinking world. ${ }^{32}$ Even with respect to the newer nations, there seems no reason why their judgments should not be enforced without review unless subject to attack on the jurisdictional grounds outhined above. ${ }^{33}$ If the inquiry is thus reduced to considering the particular case and whether there has been a failure of justice because procedural safeguards sufficient to preclude enforcement without a review of the merits are lacking, the benefit of our interstate experience may be used to extend the apphication of our basic policy of res judicata to the international area.

31 See, e.g., Ritchie v. McMullen, 159 U.S. 235 (1895); Alaska Commercial Co. v. Debney, 144 Fed. 1 (9th Cir. 1906).

32 Except for the reciprocity doctrine of Hilton v. Guyot, American courts usually have not distinguished among the various countries or political systems when enforcing judgments. In his concurring opinion in Scott v. Scott, 51 Cal. 2d 249, 254, 331 P.2d 641, 644 (1958), Mr. Justice Traynor stated: "As to judgments of courts of foreign countries, however, state courts have generally held that state law is controlling in the absence of treaties or federal legislation. ... . For the most part they have followed the rules applicable to judgments of courts of sister states." See Reese, supra note 30, at 789, 800. Even where the rule of reciprocity is in effect, as in Denmark, the courts have generally ignored the problem of reciprocity and enforced the judgments in the usual manner. See PHIITP, AMERICAN-DANISI Private Interational Law 29 (Bilateral Studies in Private Int'1 Law No. 7, 1957).

33 For several reasons nothing has been said of the defense of public policy. First, in a sense, everything in this sphere involves public policy. Second, it is believed that in the great bulk of cases any reasonably cognizable defense of public policy can be accommodated under the limitations suggested. Further, "public policy" is a brush too broad to be of significant value in conflict of laws. Cf. Katzenbach, supra note 8, at 1091, 1108 (1956); Paulsen \& Sovern, "Public Policy" in The Conflict of Lazes, 56 CouUs. L. Rev. 969, 987 (1956). 
Supplementing the policies favoring the conclusive termination of international litigation which are found in the doctrines of res judicata is another policy analogous to the domestic full faith and credit requirement. This policy is seen in the act of state doctrine that one nation will not question another's governmental acts done wliolly within the territory of the actor. ${ }^{34}$ In the United States the full faith and credit concept includes this policy of mutual respect for the acts of political equals. The same pohicy suggests that once the government of another nation has taken affirmative steps to settle a dispute througln its judicial system, the official determination by that state should not be questioned elsewliere. When combined with the recognition of federal supreniacy in the area of foreign relations, ${ }^{35}$ this suggests that the Suprene Court might well adopt a more rigorous view for the recognition of foreign judgnients than is called for by Hilton v. Guyot. At the least, it suggests that the approach of leaving this problem to be decided by the states as part of their common law developnent, with their solutions to be applied by the federal courts under Erie and Klaxon, is anomalous. ${ }^{36}$

\section{Tax Claims}

One of the heirlooms of private international law which for years misled courts in the United States in their lrandling of interstate conflicts problenis relates to the enforcenient of foreign tax claims. Tlie often repeated but seldonı analyzed rule "whicl has been enforced for at least two hundred years or thereabouts, under which these courts will not collect the taxes of foreign states for the benefit of the sovereigns of those foreign states"37 was applied to interstate cases without consideration of the differences between the policies relevant to interstate and international conflicts. While vestiges of this rehc may still haunt the international area, ${ }^{38}$ interstate enforcement of tax judgments is now assured; ${ }^{39}$ most states of the United States will also enforce sister state tax claims

34 Banco Nacional de Cuba v. Sabbatino, 376 U.S. 398, 416-20 (1964); EERENzWEIG, Confuter of Laws $\$ 48$ (1962). See text at note 49 , infra.

35 United States v. Pink, 315 U.S. 203 (1942); United States v. Belmont, 301 U.S. 324 (1937).

36 Cf. EmRenzwetg, Confuict of Laws $\$ 46$ (1962); Reese, supra note 30, at 787, 790.

37 In re Visser, Queen of Holland v. Drukker, [1928] $1 \mathrm{Ch}$. 877, 884, quoted in Sack, (Non-) Enforcement of Foreign Revemue Laws in International Law and Practice, 81 U. PA. L. REv. 559 (1933).

38 See, e.g., City of Detroit v. Proctor, 44 Del. 193, 61 A.2d 412 (1948); Wayne County v. American Steel Export Co., 277 App. Div. 585, 101 N.Y.S.2d 522 (1950); Minnesota v. Karp, 84 Ohio App. 51, 84 N.E.2d 76 (1948); cf. Banco do Brasil, S.A. v. A.C. Israel Conlnoodity Co., 12 N.Y.2d 371, 190 N.E.2d 235 (1963).

39 Milwaukee County v. M.E. White Co., 296 U.S. 268 (1935); City of New York v. Shapiro, 129 F. Supp. 149 (D. Mass. 1954). 
either by judicial decision or under reciprocal enforcement statutes. ${ }^{40}$ Further, it seems likely that the Supreme Court will eventually require the non-discriminatory entertainment of tax claims by a sister state.

The international field is still subject to the influence of the jealous sovereign theory, although the edge of the doctrine is fast being blunted by the United States tax treaty network. ${ }^{41}$ Policy considerations are different, of course, from the interstate area. Pohtical and economic theories are reflected in tax structures, and a much greater range of attitudes toward the proper function of taxes exists in the international arena than in the interstate. Likewise, the procedures for assessment and collection vary greatly. In some instances, these procedures would probably not accord with standards imposed by the United States Constitution, thus raising the question of whether those tax determinations could be constitutionally enforced in the United States. ${ }^{42}$ Also, tax structures are sufficiently complex and integrated with national economic policy to make the judicial system an awkward vehicle for the adjustments and compensations that can be negotiated and incorporated in tax treaties. Once a treaty is ratified, of course, its provisions become conclusive and compel both state and federal courts to render the prescribed assistance. In light of the view now generally taken that "taxes are what we pay for civilized society, ${ }^{\prime 43}$ and the economic interdependence of all nations, international tax collection procedures are bound to expand, and, in time, place a "reasonable restriction" on national tax structures so as to remove many of the policy reasons that underlie the ancient jealous sovereign rule. ${ }^{44}$

\section{Expropriation}

Expropriation is another area of international fiscal and economic regulation in which the approaches and procedures in the international cases vary substantially from those followed in analogous interstate matters. Governinent seizure of private assets is called expropriation or confiscation on the international level, but on the interstate level less emotion-laden terms are used, such as condemnation or escheat. The

40 See, e.g., Oklahoma v. Neely, 225 Ark. 230, 282 S.W.2d 150 (1955); City of Detroit v. Gould, 12 Ill. 2d 297, 146 N.E.2d 61 (1957); Ohio v. Kleitch Bros., Inc., 357 Mich. 504, 98 N.W.2d 626 (1959); Oklahoma v. Rodgers, 238 Mo. App. 1115, 193 S.W.2d 919 (1946). See McElroy, Enforcement of Foreign Tax Clainss, 38 U. DET. L.J. 1 (1960); GoodricH \& 66.

41 See EHRENZWeig \& Koch, Income TAX Treaties 6 (1949).

42 Id. at 230 .

43 Justice Oliver Wendell Holmes in Compania General de Tabacos v. Collector, 275 U.S. 87, 100 (1927) (dissenting opinion).

44 See Surr, Intertax: Intergovernmental Cooperation in Taxation, 7 HaRv. INT'工 I. CluB J. 179 (1966); Note, International Enforcement of Tax Claims, 50 CoLus. L. REv. 490 (1950). See also Rothkopf, Current Developments in the Field of International Tax Affairs, 44 TAXxs 87 (1966); Surrey, International Tax Conventions: How They Operate and What They Accomplish, 23 J. Taxation 364 (1965). 
eminent domain powers of the states of the United States, over tangibles for example, are constitutionally limited so that there can be a seizure only by one state and only upon payment of just compensation.

The problem of multiple seizures lias, in recent years, become significant in cases involving escheat of abandoned intangibles. To avoid the possibilities of multiple seizures, the United States Supreme Court held that due process prevents escheat by more than one state, and that conflicting claims by the states to esclieat a particular asset are within the original jurisdiction of the Supreme Court. ${ }^{45}$ Subsequently, the Court held that the only state which could seize abandoned intangibles was the state of the creditor's last known address. ${ }^{46}$ It is interesting to note that the Court fashioned this rule on considerations of convenience and reasonable allocation of the assets among the states, rather than on theoretical jurisdictional concepts. The court was dealing with an interstate problem which it felt competent to regulate.

By contrast, in an international case, Banco Nacional de Cuba v. Sabbatino, ${ }^{47}$ the Supreme Court recently reaffirmed the act of state doctrine which precludes judicial review of a foreigu expropriation fully executed withm the foreign nation. One of the rationales underlying this doctrine is the belief that the executive branch is equipped to deal more effectively with foreign expropriation than are the courts. In the Sabbatino case, the Court makes clear its distinctions between interstate and international policies:

The [act of state] doctrine as formulated in past decisions expresses the strong sense of the Judicial Branch that its engagement in the task of passing on the validity of foreign acts of state may hinder rather than further this country's pursuit of goals both for itself and for the community of nations as a whole in the international sphere. . . . Whatever considerations are thought to predominate, it is plain that the problems involved are uniquely federal in nature. If federal authority, in this instance this Court, orders the field of judicial competence in this area for the federal courts, and the states are left free to formulate their own rules, the purposes behind the doctrine could be as effectively undermined as if there had been no federal pronouncement on the subject. 48

However, we are constrained to make it clear that an issue concerned with a basic choice regarding the competence and function of the Judiciary and the National Executive in ordering our relationships

45 Western Union Tel. Co. v. Pennsylvania, 368 U.S. 72 (1961).

46 Texas v. New Jersey, 379 U.S. 674 (1965). If the creditor's last address is unknown, then the corporate domicile of the debtor can escheat until another state demonstrates a superior right to escheat.

47376 U.S. 398 (1964).

48 Id. at 423. 
with other members of the international community must be treated exclusively as an aspect of federal law. It seems fair to assume that the Court did not have rules like the act of state doctrine in mind when it decided Erie R. Co. v. Tompkins .... 49

The Sabbatino case involved expropriation of tangible assets wholly within the foreign nation. While the seizure of intangibles involves greater complexities, it seems likely that the Court, in accord with the Belmont and Pink cases, ${ }^{50}$ would take a similar view in a case involving intangibles adequately within the reach of the foreign nation. It should be borne in mind, however, that where the United States or some nation other than the expropriator has physical control over the assets, the courts in the United States would probably not recognize the expropriation as an act of state. ${ }^{51}$

So far we have discussed instances which present rather sharp distinctions in approach and policy between interstate and international cases. The problems abound with the governmental concerns of the United States-externally, as a nation in the community of nations, and internally, as a federation of equal participants. The existence of a federal law is strongly evident. The policies leading to results in these mternational conflicts cases are fairly apparent, and the interests of the federal government predominate over those of the states.

\section{III}

THE PRTVATE SPHERE: CHOICE OF LAW

In this sphere attention is directed to areas of international and interstate conflicts where doctrine is not so sharply distinguished. This is the more "private law" area of choice of law. Here policy considerations and variations in method in interstate and international cases are more subtle and obscure to the lawyers and the courts. The interests of the parties predominate, and the governmental interests involved are indirectly and principally derived from the parties to the private transaction and litigation.

\section{A. Torts}

Perhaps the inost infamous international conflicts case decided in the United States is Walton v. Arabian Am. Oil $\mathrm{Co}^{52}$ This was a diversity

49 Id. at 425 . See text accompanying note 34 , supra.

50 United States v. Belmont, 301 U.S. 324 (1937); United States v. Pink, 315 U.S. 203 (1942).

51 Banco Nacional de Cuba v. Sabbatino, 376 U.S. 398, 413 (1963). Cf. Cities Serv. Co. v. McGrath, 342 U.S. 330 (1952); Direction de Disconto-Gesellschaft v. United States Steel Corp., 267 U.S. 22 (1924).

52233 F.2d 541 (2d Cir. 1956), cert. denied, 352 U.S. 872 (1956). See Currie, On Displacement of the Law of the Forum, 58 CoLUM. L. REv. 964 (1958). 
suit brought in a New York federal district court by an Arkansas citizen against a Delaware corporation doing business in New York. The plaintiff sought to recover for injuries sustained in Saudi Arabia in a collision with the defendant's truck, which he alleged had been negligently driven by an einployee of the defendant. The evidence would reasonably have supported recovery under New York law but the plaintiff both failed and refused to allege or prove the law of Saudi Arabia. The judge refused to take judicial notice of such law and gave judgment for the defendant on the theory that the New York choice of law rule made the law of the place of injury an essential element in the case. The case might be explained as one of those infrequent instances in which the unusually firm opposing views of attorney and judge on a technical position causes the client to lose a just clain. However, the New York Court of Appeals affirmed on its view of the Erie-Klaxon doctrine, and concluded that "since the plaintiff deliberately refrained from establishing an essential element of his case, the complaint was properly dismissed."53 Notwithstanding the court's awareness of more critical views, ${ }^{54}$ it blindly applied the vested rights theory of conflicts. Divorced from the clash of personalities, the case indicates that distinctions between interstate and international cases are sometimes incorrect, particularly if choice of law is mistakenly viewed as a body of fixed doctrine to be applied in mechanical response to particular physical contacts. In cases involving the law of another state of the Union, or even of the common law system, it has become frequent practice to notice judicially the foreign law either by statute or decisional rule. ${ }^{55}$ If foreign law is not judicially noticed, another common practice is to assune that the foreign law is the same as that of the forum, and then to apply the law of the forum even when it is a creature of statute rather than of the local common law. ${ }^{56}$ Admittedly, it is easier

63233 F.2d at 546. See also Cuba R.R. v. Crosby, 222 U.S. 473, 478 (1912).

54 See 233 F.2d at $543 \&$ nn. 2a-5.

55 See Stern, Foreign Law in the Courts: Judicial Notice and Proof, 45 CarTr. L. REv. 23 (1957). The UNIForar Judictar NoTICE of Foreicn LAW ACT, 9A U.L.A. 550 (1965) has been adopted in 27 states. Ten others have similar judicial notice statutes, 9A U.I.A. 551. Currie, supra note 54, at 972 . Others have reached a similar result by decision, e.g., Choate v. Ransom, 74 Nev. 100, 323 P.2d 700 (1958) ; Saloshin v. Houle, 85 N.H. 126, 155 Atl. 47 (1931). The statutes of only seven states purport to extend judicial notice to foreign countries. Cavers, The Choice-of-Law Process 270 \& n.7 (1965).

66 The presumptions appled in absence of proof of foreign law take various forms to prevent a failure of justice. The court may presume foreign law is the same as the common law of the forum and may even include statutory law of the forum. In addition, courts sometimes presume that "fundamental principles" of all legal systems are similar. See Tidewater Oil Co. v. Waller, 302 F.2d 638 (10th Cir. 1962). This view of "rudimentary tort principles" was argued by plaintiff but rejected by the court in the Walton case. All of these presumptions are techniques leading to the application of the familiar law of the forum. See GoodRICH $\S 83$; Note, Effect of a Failure to Prove the Law of a Foreign Country, 51 CaxIF. L. REv. 632 (1963). 
in interstate cases than in international ones for a court either to apply its own law by using one of these presumptions or to ascertain foreign law. Traces still exist of the attitude reflected in Holmes' statement referring to the presumptions of sinilarity of laws:

[T] he presumption should be limited to cases in which it reasonably may be believed to express the fact. Generally speaking, as between two common law countries, the common law may reasonably be presumed to be what it is decided to be in the other, in a case tried in the latter state. But a statute of one would not be presumed to correspond to a statute in the other, and when we leave common law territory for that where a different system prevails obviously the limits must be narrower still..$^{57}$

On the other hand, many American courts may be more inclined in international cases to apply forum law if only because of their unfamiliarity with the law of foreign countries. ${ }^{58}$ This may be done by the presumptions noted above if it is found that the foreign law is not adequately proved, or, if proved, by use of other techniques such as renvoi or characterization. Even so, in the international cases a court is most bikely to convince itself that foreign law governs and then to find that the limited nature of the presumptions as a vehicle for applying forum law creates a conceptual void as occurred in Walton.

The currently evolving policy-oriented method of solution of interstate and international conflicts cases would cut through this welter of presumptions to conclude that requiring proof of foreign law is a false problem created by misplaced conceptualism. A court, as part of a legal system, does not exist in a substantive law vacuum. Its function is to settle controversies by deciding them according to its standards of justice. These standards are articulated in the law with which the court is most familiar, the law of the forum. When a case is submitted to the court for decision, even on an elementary theory of arbitration, the parties can reasonably expect the court to decide it according to its usual rules of decision unless one of the parties appropriately indicates the relevance of a foreign rule and his rehance upon it. ${ }^{50}$ When a competing rule of a

57 Cuba R.R. v. Crosby, 222 U.S. 473,479 (1912). In an carlier famous vested rights case, Holmes stated a corollary to this view in requiring dismissal of a suit where the procedures of the forum could not accommodate the "right" given at the place of injury. Slater v. Mexican Nat'I R.R., 194 U.S. 120 (1904).

58 Ehrenzweig, Fragistas \& Yiannopoulos, Amarrican-Greet Prtvate Internationat LAw (Bilateral Studies in Private International Law No. 6, 1957); Ehrenzweig, Interstate and International Conflicts Law: A Plea for Segregation, 41 MnN. L. REv. 717, 723 (1957); Nussbaum, The Problem of Proving Foreign Law, 50 Yade I.J. 1018 (1914). Yiannopoulos, Wills of Movables in American International Conflicts Law, 46 Calif. L. Rev. 185 (1958).

59 See Currie, supra note 52, at 1026; see also EmRenzweig, Confuict or Laws $\$ 129$ (1962); GOODRICH § 83. 
related state is shown to have relevance, then the court, by analyzing the purposes and policies of the competing rules in light of the transaction involved, can decide which should appropriately be used by the court to resolve the litigation before it.

A danger exists in the international cases that the court will have greater difficulty in appreciating the policy force of a foreign rule stated in unfamiliar terms. In addition, there are hikely to be fewer areas in which the policies underlying the foreign and forum rules are common to both nations. This requires a greater effort on the part of attorneys and courts to guard against the mirage of a false conflict, that is, assuming a conflict where the purportedly competing rules or their underlying policies actually require the same result. An example is a famous case in which Judge Learned Hand delivered an opinion which has since been an enigma in conflict of laws. In Scheer v. Rockne Motors Corp., ${ }^{60}$ a $\mathrm{New}$ York automobile dealer provided his salesman with a car to cover his sales territory in New York and Pennsylvania. The salesman invited a lady friend to acconipany him on an errand to Windsor, Ontario, and while in Ontario, the car turned over and severely injured the lady, who sued the owner in federal district court in New York. The lower court instructed the jury that the defendant could be held hable under Ontario law if the car was used with his permission. The court of appeals reversed and stated: "It is clear that the defendant did not give hin authority to go to Canada merely by giving him the car. Unless more than that was shown, the law of Ontario could not reach the defendant. . ." curious thing is that a New York statute providing for auto owner's liability was similar to the Ontario statute. ${ }^{62}$ Althougl the court discussed the territorial limitations of the New York act, ${ }^{63}$ it did not consider whether any real conflict existed if the law of both states involved reached the same result. Should the fortuitous ${ }^{64}$ nature of an international, or interstate, case defeat recovery when local cases in either state would provide relief? In Scheer the similarity of law is marked.

An equally questionable result was reached in Victor $v$. Sperry, ${ }^{65}$ although the similarity of law was less marked. This was a California

0068 F.2d 942 (2d Cir. 1934).

$61 \mathrm{Id}$. at 944.

62 N.X. Vemere and Trafitc ACT, \& 59. See Young v. Masci, 289 U.S. 253 (1933); CAVERS, op. cit. supra note 55 , at 89 . The judge's concern may have been to prevent unfair surprise to the defendant even though the facts preclude it in this particular case. Weintraub, A Method for Solving Conflict Problems-Torts, 48 CoRN. L.Q. 215, 240 (1963).

0368 F.2d at 944. Cf. Ehrenzweig, Vicarious Liability in the Confict of Laws, III, 69 YALE L.J. 978, 980 (1960).

04 See CAVERS, supra 57, at 311.

65163 Cal. App. 2d 518, 329 P.2d 728 (1958); discussed critically in Weintraub, supra note 62 , at 236 . 
case in which a Californian riding as a guest was injured as the result of a collision in Mexico between two California drivers. The injured guest brought suit against both drivers and the consenting owner of the other car, relying on the Mexican rule which provided for owner's liability without fault. The court held that an action based on the Mexican statute would not be enforced against the owner because liability without fault was contrary to the public policy of California, even though both drivers were found negligent and California has a statute inposing liability on consenting owners for negligent operation of their automobiles. ${ }^{.0}$ Again it would appear that the court was misled by the terminology of the foreign rule to refuse recovery even though all parties were citizens of the forum, and liability would have resulted in either state if the accident had occurred there and all the parties were nationals of that state. ${ }^{07}$ Although this problem of spurious conflicts may be more prevalent in international cases because of overconcentration on strange aspects of foreign law and lack of understanding of the foreign policies, it also often occurs in interstate cases. ${ }^{.8}$ The technique of identifying spurious conflicts, incident to the use of a policy-oriented method in choice of law, can avoid overly blind administration of justice.

If the purposes of the competing rules offered by the parties are compared, the apparent conflict may inelt away as it becomes apparent that those purposes can be satisfied by the application of either rule. Lauritzen v. Larsen ${ }^{60}$ illustrates the point. The case involved a clain for a maritime tort under the Jones Act ${ }^{70}$ by a Danish seannan, who, in New York, signed on a ship of Danish flag, registry and ownership. The ship's articles, written in Danish, provided that crew rights were to be governed by Danish law and the employer's contract with the Danish Seaman's Union, of which the plaintiff was a member. The seaman was injured aboard ship in Havana Harbor. Suit was brought in the federal district court in New York after the seaman had been paid the amount due under the purportedly exclusive Danish Law. Notwithstanding the literal application of the Jones Act to "any seaman," th1 the Supreme Court held that Danish law governed; it viewed the matter as "simply dealing with a problem

68 CAC. VeHrTCLE CODE \& 17150. Note that because of its conclusion the court never reaches questions such as whether the negligence of the guest's host would be imputed to him to preclude suit against the other owner. However, this particular point does not seem to be in issue since the judgment was affirmed as to the award of damages against the two drivers.

o7 Cf. CAvers, op. cit. supra note 55 at 89,151 .

88 See Ehrenzweig, Vicarious Liability in the Confict of Laws, III, 69 YALE L.J. 978, 982 (1966); Weintraub, supra note 62, at 217.

69345 U.S. 571 (1953).

7041 Stat. 107 (1920), 46 U.S.C. § 688 (1964).

71 Ibid. 
of statutory construction rather commonplace in a federal system by which courts often have to decide whether 'any' or 'every' reaches to the limits of the enacting authority's usual scope or is to be applied to foreign events or transactions." ${ }^{272}$ The Court considered the history and purpose of the act, and concluded that its application was not mandatory and that its purpose would not be frustrated by nonapplication in this factual setting. Then, turming to the question whether private international law considerations indicated an application of the Jones Act, the court said:

Maritime law, like our municipal law, has attempted to avoid or resolve conflicts between competing laws by ascertaining and valuing points of contact between the transaction and the state or governments whose competing laws are involved. The criteria, in general, appear to be arrived at from weighing ... the significance of one or more connecting factors between the shipping transaction regulated and the national interest served by the assertion of authority. ${ }^{73}$

Using this method, the Court appraised the significance of the contacts and the rules of law imcident to them and found an "overwhelming preponderance in favor of Danish law" and "no justification for interpreting the Jones Act to intervene between foreigners and their own law because of acts on a foreign ship not in our waters. ${ }^{275}$ The inethod folowed by the Court would avoid the mechanistic application of policy frustrating rules. ${ }^{76}$ Further, if this approach is followed, the reacl of the

72345 U.S. at 578-79. See Cheatham and Reese, Choice of the Applicable Law, 52 CoLOMr. L. REv. 959, 961 (1952). A similar approach was taken in the excellent opinion in Bernkrant v. Fowler, 55 Cal. 2d 588, 360 P.2d 906, 12 Cal. Rptr. 266 (1961). This was an interstate case in which the court, by Mr. Justice Traynor, stated: "The Legislature, however, is ordinarily concerned with enacting laws to govern purely local transactions, and it has not spelled out the extent to which the statute of frauds is to apply to a contract having substantial contacts with another state. Accordingly, we must determine its scope in the light of applicable principles of the law of conflict of laws." 55 Cal. $2 \mathrm{~d}$ at 594, 360 P.2d at 909, 12 Cal. Rptr. at 269. See Note 49 CAIIF. L. REv. 962 (1961).

73345 U.S. at 582.

74 Id. at 592 .

75 Id. at 593 .

76 See Currie, The Silver Oar and All That, 27 U. CHI. L. Rev. 1, 65 (1959), which discusses in detail Romero v. Int'l Terminal Operating Co., 358 U.S. 354 (1959), a case in which the Court followed the method outlined in Lauritzen. See also Comment, Wrongful Death at Sea, 51 Carrfr. L. Rev. 389 (1963). In Urda v. Pan-Am. World Airways, 211 F.2d 713 (5th Cir. 1954), the court refused to entertain a suit under Brazilian law for death resulting from a crash in Brazil of a plane flying from Argentina to Trinidad. The deceased, a steward aboard the plane, was a resident of Florida who had been hired in Florida for service partly in and partly out of that state. The court held that the Florida workmen's compensation act, which gave an exclusive remedy, was applicable. The court unfortunately muddled the case by taking refuge in "public policy" and also stressing the appellant's acceptance of payments tendered under the Florida act; it concluded that the appeal was "moot." A factually analogous interstate case, except for the forum relationship, is Stacy v. 
forum's law can be determined in either interstate or international transactions without the construction of separate systems of conflicts doctrine. A warning must be offered, however, that different pohicy strengths exist in factually similar interstate and international cases.

One of the most respected state courts in the United States, the New York Court of Appeals, has been a leader in the transition of conflict of laws from a dogmatic to a policy-oriented method. In applying a policyoriented method of reaching choice of law solutions, that court has not specifically atteinpted to distinguish between international and interstate cases but has permitted its appraisal of the relevant policies to accommodate the differences that exist. ${ }^{77}$ The recent Babcock $v$. Jackson case ${ }^{78}$ involved substantial international contacts. In that case, two New York residents took another New Yorker as their guest on a weekend trip to Canada. While in Ontario, the host lost control of his car and the guest was injured. Later, the guest sued the host in the New York courts, relying on the New York rule which permitted an injured guest to sue his host, and the host pleaded the Ontario guest statute which precluded recovery. The court used the forum rule, stating that it was "the law of the jurisdiclion which, because of its relationship or contact with the occurrence or the parties, has the greatest concern with the specific issue raised in the litigation." In relating choice of law to the particular issue, the court noted that the rules concerned with the relationship of the parties could be supplied by a different jurisdiction from that which supplied the rules relating to the standard of care for determining neghgence. The court then considered the purpose of each competing rule and concluded that Ontario had "no conceivable interest in denying a remedy to a New York guest against his New York host for injuries suffered in Ontario by reason of conduct which was tortious under Ontario law"; ${ }^{80}$ whereas New York was most concerned as the residence of the parties and the place where their relationship arose and where the trip began and was to end. The court rehed heavily upon its leading conflicts case in contracts, Auten v. Auten ${ }^{81}$ an international case, and the Restatement Second, which is prinnarily concerned with interstate cases. ${ }^{82}$ These

Greenberg, 9 N.J. 390, 88 A.2d 619 (1952); here the New Jersey forum, where the accident occurred, applied the New York workman's compensation law to which the parties were subject because they were New York residents and the employment contract had been entered into there. The New Jersey Court, however, appropriately relied on its analysis of the policies behind the two competing laws. Cf. GoodrICH $\S 191$.

77 This approach has met with some criticism. EnRrinzweIg, Conflict of LAws, 463, 548 (1962). Cf. Ehrenzweig, Comments on Babcock v. Jackson, 63 Coros. L. REv. 1243 (1963).

7812 N.Y.2d 473, 191 N.E.2d 279, 240 N.Y.S.2d 743 (1963).

79 Id. at 481,191 N.E.2d at 283,240 N.Y.S.2d at 749 (1963).

80 Id. at 482,191 N.E.2d at 284,240 N.Y.S.2d at 750 (1963).

81308 N.Y. 155, 124 N.E.2d 99 (1954).

82 Restatemient (Second), Conflict of Laws $\$ 379$ (Tent. Draft No. 8, 1963). 
authorities adopt a policy-oriented method without regard to whether the transactions are interstate or international. Indeed, to appreciate the New York cases and their approach, it is necessary to consider them together, whether they are of interstate or international character. ${ }^{83}$

At times it is suggested that this flexible approach is plaintiff oriented because of the ease with which it can be manipulated to show a balance in favor of recovery. ${ }^{84}$ The Tramontana case was one in which the sentimental pressures of sympathy for the plaintiff were great indeed. ${ }^{85}$ Yet the court resisted these pressures toward the favorable law, and after a thorougli policy analysis denied recovery. The husband of the plaintiff in this case was a Maryland citizen and a member of a United States Navy band on tour im South America. The band was flying in a Umited States Navy plane from Argentina to Brazil when the plane collided over Brazil with one of the Brazilian defendant's planes and the husband was killed. The law of Brazil hmited recovery to an equivalent of 170 dollars. The widow sued for 250,000 dollars in the federal district court in the District of Columbia where defendant was subject to jurisdiction. The plaintiff urged the application of the law of the forum, for the District had no himitation on damages: She relied on Kilberg v. Northeast Airlines $^{80}$ and Babcock. A Maryland statute required the application of the law of the foreign jurisdiction in whiclr the wrongful act, neglect or default occurred. The court initially noted the international nature of the case and its freedom from the coverage of the full faith and credit clause. There was no international agreement that compelled the application of foreign law, so the court was

83 See Cavers, Cheatham, Currie, Ehrenzweig, Leflar, Reese, Comments on Babcock v. Jackson, 63 Corus. L. REv. 1212 (1963). These authors give the Babcock case general approval, except for Ehrenzweig who fears the "center of gravity" and "significant relationship" approach because "if divorced from policy analysis these formulas invite a mechamieal counting of 'contacts.' " 63 Corus. L. Rev. at 1244. See also Comment, The Second Conflicts Restatement of Torts: A Caveat, 51 CAITF. L. Rev. 762, 778 (1963). But Cavers suggests, in reference to the Babcock approach of using the rule which has the most significant contact with the matter in dispute, that "the question-begging character of that phrase is a clear incitement to assess the respective policies and equities bearing on the issue before the court." 63 Coluss. L. Rev. at 1220 n.5. Cf. Gooprice 166, 172. The courts must have a chance to render justice in a thoughtful fashion; it is they, after all, who have the greatest responsibility in this area. See Traynor, Is This Conflict Necessary?, 37 TEXAs L. REv. 657, 668, 675 (1959).

84 See Lefiar, supra note 83 , at 1248 . Note, however, that the primary purpose of tort law is to compensate those injured as the result of the activities of another. Consequently, if protection is afforded to the victim by one reasonably applicable law, a competing rule of non-recovery should be shown to have a clearly superior policy claim before it should be applied. Cf. Cavers, op. cit. supra note 55, at 139, 159; Weintraub, supra note 62, at 238, 249. 85 Tramontana v. S.A. Empresa de Viacao Aerea Rio Grandense, 350 F.2d 468 (D.C. Cir. 1965).

889 N.Y.2d 34, 172 N.E.2d 526, 211 N.Y.S.2d 133 (1961). 
free to explore the question presented by this appeal in the hight of the newer concepts of conflict of laws. Our conclusion that the District Court properly applied the Brazilian limitation rests upon an examination of the respective relationships of Brazil and the District of Columbia with the accident, and with the parties here involved; and a consideration of their respective interests in the resolution of this issue. ${ }^{87}$

The court considered the concern of Brazil for the financial integrity of its national airline, the lack of any prior relationship between the decedent and the defendant, the fact of the decedent's and plaintiff's nonresidence in the District (so that the District was a disinterested forum available only because the defendant did business there), the likelihood that Maryland, the plaintiff's residence, would apply the Brazilian limit, the 600 per cent depreciation in Brazilian currency since the accident, and the inpact of a possible recovery on international economic, political and legal attitudes. After appraising these many factors, the court concluded that the District had no interest that would be forwarded by the application of its law, and that Brazil had significant interests that called for the application of its limitation. The court's displacement of the forum law by that of Brazil on the issue of the limitation of damages appears just, ${ }^{88}$ even though it is contrary to sympathetic preference for widows over foreign corporations. But even if one should for some reason quarrel with the result, the approach is an infinite improvement over a mechanical place-of-wrong dogma which in this case would have produced the same result. The court is aware of what it is doing and why it is doing it and is giving thorough consideration to the alternatives. It is a thinking approach - the actual claims of the parties are not disregarded because of an overgloss of conceptualism. ${ }^{89}$

While the court distinguished this international case from interstate cases, the distinction was inconsequential so far as the choice of law method was concerned. The differences between the interstate and international cases were accommodated in the policy analysis and the evaluation implicit in the approach to the problem. When a court applies doctrinal concepts, such as "the law of the place of wrong governs torts,"

87350 F.2d at 471.

88 See Cavers, op. cit. supra note 55, at 147: "By entering the state or nation, the visitor has exposed himself to the risks of the territory and should not expect to subject persons living there to a financial hazard that their law had not created."

${ }^{89}$ After the appeal was heard, the Court of Claims of the United States reconimended an equitable award of $\$ 25,000$ to each of the families of the eighteen band members killed in the crash, because prior to the flight the Navy failed to follow its usual practice of distributing private insurance forms to the band members. Armiger Estates v. United States, 339 F.2d 625 (Ct. Cl. 1964). No action existed under the Federal Tort Claims Act because the act excludes claims arising in foreign countries, 28 U.S.C. $\$ 2680(\mathrm{k})$. 
it blinds itself to the real claims of the parties and the states and a just result is frustrated or reached fortuitously because the real issues are concealed from the court by its own conceptualism. It is submitted that we are beginning a new era in conflicts, ${ }^{90}$ in which method will mature and policy will adequately be considered, thus accommodating any interstate and international distinctions implicit in tort litigation.

\section{B. Contracts}

The analysis suggested by the tort cases is equally applicable to choice of law problems arising in contracts cases. The leading contracts choice of law case that adopts a policy-oriented approach is Auten $v$. Auten, ${ }^{91}$ an international case which involved a separation agreement made in New York between an English husband and wife under wlich the husband was to pay 50 pounds per month in England for the support of his wife and children. He failed to do so and sle brought suit, first in England and later in New York where he defended on the ground that, under New York law, the contract had been repudiated, thus terminating the plaintiff's rights. The court discussed the various cases, interstate and international, applying different theories and doctrimes current in the conflict of laws. Then, relying on one of its own prior cases,$^{92}$ the court decided to apply the law of the place "which has the most significant contacts with the matter in dispute, ${ }^{\prime 93}$ and concluded that this place was England and that English law would sustain this contract for the support of an English inother and children in England at the expense of the husband who fled England with his paramour. The court explained its reasoning as follows:

[T] he merit of its approach is that it gives to the place "having the most interest in the problem" paramount control over the legal issues arising out of a particular factual context, thus allowing the forum to apply the policy of the jurisdiction "most intimately concerned with the outcome of [the] particular litigation." ... Moreover, by stressing the significant contacts, it enables the court, not only to reflect the relative interests of the several jurisdictions involved, ... but also to give effect to the probable intention of the parties and consideration to "whether one rule or the other produces the best practical result." 94

This attention given to the policies expressed in the law of the different

${ }^{90}$ See Cheatham, supra note 83 at 1231. Cf. Rheinstein, How to Review a Festschrift, 11 Axr. J. CoMr. L. 632, 660 (1962).

91308 N.Y. 155, 124 N.E.2d 99 (1954).

92 Rubin v. Irving Trust Co., 305 N.Y. 288, 113 N.E.2d 424 (1953).

93 Id. at 305, 113 N.E.2d at 431, quoted with approval in Auten v. Auten, 308 N.Y. at 160,124 N.E.2d at 102 .

94308 N.Y. at 161, 124 N.E.2d at 102. 
jurisdictions in a matter of private litigation should accommodate the differences between interstate and international cases more successfully than an automatic application of older mechanical formulas of the conflicts of law..$^{95}$

The two most significant policies in the area of contracts, that of giving effect to the parties' intention and of sustaining their agreement, ${ }^{00}$ are accorded full weight by a policy-oriented method. The interests of New York would not be furthered by applying its alleged repudiation rule to this contract because New York would "have no desire to make this state a haven for fugitive husbands." England were furthered by its nonrepudiation rule which would hold the fugitive husband to his agreed obligations to support the deserted family at their residence in England. The prospect of the husband being accorded a bootstrap defense to the suit on his contract, which he had previously failed to perform, likewise would not accord with the concept of justice in the minds of most. None of these policy considerations appear to be related to the circumstance of whether the case is an interstate or international one.

The policy of giving effect to the parties' intention supports express choice of law clauses in contracts. Historically, the recognition of party autonomy in choice of law probably moved from international to interstate doctrine in its developnent, so many aspects of this concept are indistinguishable between international and interstate cases. ${ }^{98}$ If one state imposes a restriction designed to protect one of the parties to the transaction, for example, a limitation on capacity to contract, the purposes of such a restriction and its relation to the parties and the issue before the court must be considered. In this process there may be room for a some-

95 Vanston Bondholders Protective Comm. v. Green, 329 U.S. 156, 161-62 (1946): "In determining which contact is the most significant in a particular transaction, courts can seldom find a complete solution in the mechanical formulae of the conflicts of law. Determination requires the exercise of an informed judgment in the balancing of all the interests of the states in order best to acconmodate the equities among the parties to the policies of those states."

${ }^{90}$ See Cheatham, Problems and Methods in Conflict of Laws, 1960 ACAD. INT'L L., RECUEII des Cours 237, 279 (1960); Rabel, Conflicts Rules on Contracts, in TrE Conpuret of Laws aNd International Contracts 127 (1951). See also Ehrenzweit, Conflict of Laws 466 (1962); Gooprich 199; RABET, THE Conflict of Laws 362, 376 (2d ed. 1960); Weintraub, The Contracts Proposals of the Second Restatement of Confict of Laws-A Critique, 46 IOWA L. REv. 713, 719, 726 (1961).

${ }^{27}$ Sackler v. Sackler, 47 So. 2 d 292, 294 (Fla. 1950).

98 EHRENZWeig, Conflict of LaWs 460-61 (1962); Radet op. cit. sulpra note 98, at 365. Of course, the intention of the parties must be freely expressed; an adhesion contract destroys this element and renders a choice of law clause ineffective. Ehrenzweig, Adhesion Contracts in The Conflict of Laws, 53 Colum. L. REv. 1072 (1953); EnRenzweto, Confhict of LAws 455-58 (1962); GoODRICH 202. 
what greater provincialism on the part of the forum in an international case than in an interstate one, but the risk is not great unless the court goes back to the older "mechamical formulae." Even so, such provincialism has not prevailed in the United States, for the courts apparently have seldom invalidated contracts wliere there was a reasonably related validating law. ${ }^{100}$

When the restrictions on the parties involve inatters of governmental concern in the public sense, for example, excliange controls or war time regulations, then the policy shifts to that highly sensitive area previously discussed in whicl distinct differences may result from federal or international treaty policies. In Perutz v. Bohemian Discount Bank in Liquidation, ${ }^{101}$ for example, a pension contract between an employer and employee had been made and was to be performed in Czechoslovakia. The court accepted the defendant's contention that the Czechoslovakian exchange regulations had been recognized by the United States under the Bretton Woods Agreement, and consequently the contract was unenforceable in New York without a Czecli foreign exchange hicense.

Absent a treaty or executive agreement, however, sucli a case would be determined by the policy outlined above, emphasizing the intention of the parties and seeking to validate the contract if possible. An example is Southwestern Shipping Corp. v. Nat'l City Bank ${ }^{102}$ in which it was asserted that a contract by a New York bank to pay to the New York plaintiff-assignee certain dollar sums coming to the bank from an Italian concern was invalid. The bank paid the assignor and requested lim to send the check back if he had assigued these funds. The assignor absconded and the bank defended on the theory that the excliange contracts by whicl the Italian firm obtained the dollars violated Italian exchange controls that fell within the Bretton Woods Agreement. Tlie court held that the New York transaction was not tainted by the assignor's dealings in Italy and that the International Monetary Agreement did not apply. Once the "public" aspects were set aside, the court sustained the contract under New York law. The case lost its "conflicts" character because there was no policy against enforcement of the contract. ${ }^{103}$

The wide spread adoption in the United States of the Uniform Commercial Code ${ }^{104}$ may call for a sliglitly different approach in international

09 Cf. CAVERs, op. cit. supra note 55, at 196 (1965); GoodrICH 201.

100 Cf. EHRENZWEIG, CONELXCT of LAWS 477, 479, 489 (1962).

101304 N.Y. 533, 110 N.E.2d 6 (1953).

1026 N.Y.2d 454, 160 N.E.2d 836 (1959) cert. denied, 361 U.S. 895 (1959).

103 Cf. Banco do Brasil, S.A. v. A.C. Israel Commodity Co., 12 N.Y.2d 371, 190 N.E.2d 235 (1963).

104 The Uniform Commercial Code has been adopted in at least 42 states of the union See D.L.A., Uniforar Conamerctal Code 5 (Supp. 1965). 
cases than in interstate cases, although the result will follow the interstate pattern. The Code provisions call for its application when the state of enactment bears an "appropriate relation" to the transactions in question, unless the parties have chosen the governing law. ${ }^{105}$ Thus, if a foreign nation and a state of the United States are the competing sources of rules of decision, the forum would often be called on to apply its own law if it had adopted the Uniform Commercial Code. Admittedly, the "appropriate relation" necessary under the statute is subject to construction, and one reasonable view could be that this provision does not require more or less of a relation than any other case to justify the application of forum law. However, it must be conceded that it is possible for the forum, in international cases particularly, to lean more heavily on the Code as a legislative mandate to apply forum law than on its own cases permitting essentially the same thing. ${ }^{108}$

\section{CONCLUSION}

Other areas of choice of law could be explored in detail, but the essential differences between interstate and international cases seem to follow the same broad outhine. Where national interests and governmental pohicies become significant, there is of necessity a difference between the two types of cases. Where the governmental interests recede to the point where they simply support private interests, there is little difference in the treatment of interstate and international cases under the currently evolving policy-oriented choice of law method in the United States.

The plea made by Professor Ehrenzweig for segregation of the two areas is eminently justified where the mechanical doctrines of the First Restatement are used by the courts, for those doctrines blind the courts to the real issues between the parties relevant to conflict of laws. Likewise, the plea should be heeded to encourage thorough consideration of the many conflicting policies that vary in force and applicability in international and imterstate cases. Attorneys, and through them the courts, should ever be cautious about assuming that conflict of laws questions and the policy values relevant to them are alike in interstate and international cases. However, if a thorough policy analysis is made in any case, the variations in policy with which the court will be dealing should adequately reflect the distinctions that exist. The bencl and bar in the United States can, and will, respond more quickly and effectively to identification of policies of varying strengths in different cases than to participation in the creation of a separate structure of conflict of laws

105 U.I.A., UnIforax Comarerciax CODE \& 1-105. See Nordstrom, Choice of Law and the Uniform Commercial Code, 24 OHIo I. J. 364 (1963).

108 Cf. CaVERs, op. cit. supra note 55, at 193 n.24; GoodrICE 202. 
for international cases. By lending our efforts to improving the one, we can improve both.

The lawyer in our federal system is accustomed to dealing with variations between cases because of the source of applicable law and policies. When considering a case, he regularly analyzes the facts and identifies the problems according to the legal system to which they have the predominant contact. He first considers whether there is an applicable forum statute, state or federal (and federal here includes treaties and international compacts). If relevant legislation exists, the lawyer determines if it controls by reason of its purpose or intent. If there is no statutory regulation, he moves to the cases and decisional rules and again determines their applicability or analogous authority. Eacl of these steps requires that lie exercise a basic skill of evaluation; this means an appraisal of the relevant purposes and policies of his material, representing sources of rules of decision for his particular problem. This is his stock in trade. This is what nakes him a lawyer.

Now that court and counsel, in the field of conflict of laws, are looking at problems, policies, and results-thanks to our many gadfly scliolars-rather than blindly hiding behind vested rights cliches, the great need for distinguishing between international and interstate cases is being met in most cases. Consequently, it is submitted that if the older mechanical doctrines are discarded, the newer method will meet the needs in this area without attempting to structure separate systems of interstate and international conflict of laws. Perhaps too, the architectual results so far do not commend the commitment to build still another structure patterned after those that clutter the landscape. 